\title{
SISTEM LAYANAN ANTAR PADA RESTORAN BERBASIS ANDROID
}

\author{
Endyatna Puthut Bagus Pratama, Sumarsono, Elizabeth Nurmiyati Tamatjita \\ Sekolah Tinggi Teknologi Adisutjipto, Bantul, Yogyakarta
}

\begin{abstract}
The business restaurant is growing. In this fast business is need application mobile for customer satisfaction. This system his many applications. They are customer, manager, web kitchen and delivery application. This application is using android Operating System. Using that application by maps for knowing the places of customer. The results are 100\% for delivery service, $93 \%$ to level of effective and efficient, $97 \%$ to time service system and $97 \%$ of delivery order system.
\end{abstract}

Keywords: android, restaurant, service

\section{Pendahuluan}

Perkembangan teknologi yang sangat cepat telah membawa manusia memasuki kehidupan yang berdampingan dengan informasi dan teknologi. Dengan teknologi informasi yang berkembang saat ini, pengelolaaan informasi dapat dilakukan secara lebih aktual dan optimal. Penggunaan teknologi informasi bertujuan untuk mencapai efisiensi dalam berbagai aspek pengelolaan informasi, yang ditunjukkan untuk dengan kecepatan dan ketepatan waktu pemrosesan, serta ketelitian dan keakuratan informasi.

Banyaknya bisnis kuliner yang semakin bersaing, disamping menu yang disajikan, layanan restoran juga sangat berpengaruh yaitu dalam memberikan kepuasan kepada pelanggan. Dengan alternatif layanan delivery pada restoran akan memudahkan pelanggan dalam memesan makanan tanpa datang ke restoran. Melihat bisnis kuliner dunia nyata yang menerapkan layanan delivery restoran secara manual mempunyai dampak kinerja yang kurang efisien dan efektif. Sehigga dalam segi waktu dan pengelolan restoran bergantung pada kinerja setiap pegawai restoran.

Untuk lebih meningkatkan pelayanan, maka diterapkan sistem aplikasi layanan delivery berbasis android. Karena dengan aplikasi tersebut pelanggan dapat melihat daftar menu melalui smartphone berbasis android dan memesan order pesanan dengan nyaman tanpa menguras tenaga. Dengan sistem ini menu makanan yang dipesan oleh pelanggan akan diterima pada server yang terdapat pada restoran, kemudian server mengolah data pesanan dan menampilkan letak koordinat pemesan melalui GPS (Global Positioning System) sehingga memudahkan petugas delivery untuk mengetahui alamat pelanggan serta membawa order pesanan dari pelanggan dengan aman, nyaman dan tepat sasaran.

Dari uraian di atas akan dibangun sebuah sistem aplikasi "SISTEM LAYANAN ANTAR PADA RESTORAN BERBASIS ANDROID“. Dimana aplikasi ini nantinya dapat membantu dan memajukan restoran dalam meningkatkan pelayanan delivery yang dapat diakses oleh pelanggan dan memudahkan pemilik restoran dalam mengelola restoran. 


\section{UML (Unified Modelling Language) dan ORM (Object Relational Mapping)}

\subsection{UML (Unified Modelling Language)}

UML (Unified Modelling Diagram) adalah sebuah bahasa yang berdasarkan grafik/gambar untuk memvisualisasikan, menspesifikasikan, membangun, dan mendokumentasikan sebuah sistem pengembangan software berbasis $O O$ (Object Oriented). UML mempunyai 13 diagram, yang digunakan untuk membuat pemodelan sistem pada tugas akhir ini adalah 3 diagram yaitu :

1. Activity diagram.

2. Use case description dan Use case diagram.

3. Class diagram, adapun class diagram yang digunakan adalah ORM (Object Relational Mapping).

\subsubsection{Activity Diagram}

Diagram activity berfokus pada aktifitas-aktifitas yang terjadi dalam suatu proses tunggal. Diagram ini menunjukkan bagaimana aktifitas-aktifitas tersebut bergantung satu sama lain. Berikut simbol-simbol yang terdapat pada diagram activity dapat dilihat pada Gambar 1.

\begin{tabular}{|c|c|}
\hline Silumbal & Kelorangan \\
\hline - & Tilik awal \\
\hline - & Titik Akbir \\
\hline . & Aktifitas \\
\hline 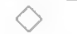 & Piliban unruk pengambilan kepulusan \\
\hline - & Fork; Untuk menunjulkan kegialan yang dilakukan secara paralel \\
\hline तो & Rake; menunjukkan adanya dekomposisi \\
\hline$\geq$ & Tanda wakrus \\
\hline$\sum$ & Tanda penerimaan \\
\hline$\otimes$ & Aliran akhir (Flow final) \\
\hline
\end{tabular}

Gambar 1 Simbol Diagram Activity

\subsubsection{Use Case Diagram}

Use case adalah diagram yang menunjukkan fungsionalitas interaksi antara actor dan sistem. Use case diagram merupakan gambaran graphical dari beberapa atau semua actor, use case, dan interaksi diantara komponen-komponen yang memperkenalkan suatu sistem yang akan dibangun. Berikut simbol dari use case diagram dapat dilihat pada Gambar 2.

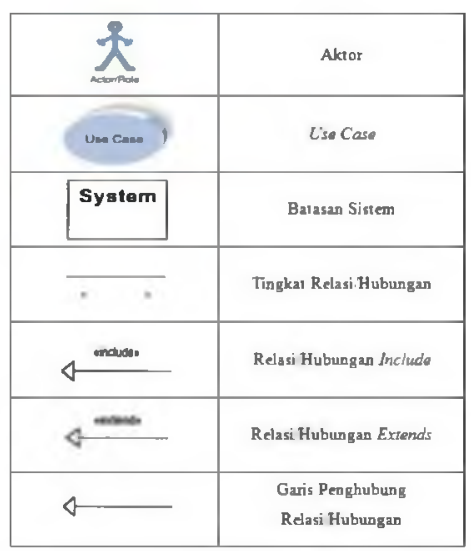

Gambar 2 Simbol Use Case 


\subsubsection{Class Diagram}

Class Diagram adalah sebuah spesifikasi yang apabila diinstansiasi akan menghasilkan sebuah obyek dan merupakan inti dari pengembangan dan desain berorientasi obyek. Class diagram menggambarkan struktur dan deskripsi class, package, dan object beserta hubungan satu sama lain seperti containtment, pewarisan, asosiasi, dan lain-lain. Berikut simbol class diagram. Dapat dilihat pada Gambar 3.

\begin{tabular}{|c|c|}
\hline Class 1 & \multirow{3}{*}{ Kelas } \\
\hline Antibuta \& & \\
\hline - Operation II) & \\
\hline $\begin{array}{c}\text { Attribute nameiderived } \\
\text { attribute name }\end{array}$ & Atribut \\
\hline Operation name () & Nama Operasi/Metode \\
\hline 1..* Verb phrase 0.1 & Tingkat Relasi/Hubungan \\
\hline
\end{tabular}

Gambar 3 Simbol Class Diagram

\subsection{ORM (Object Relational Mapping)}

ORM (Object Relational Mapping) melakukan pemetaan tabel-tabel pada basis data relasional dengan suatu class yang ada pada bahasa pemrograman berorientasi obyek. ORM berfungsi untuk memetakan entitas menjadi tabel dan atribut menjadi kolom tabel.

\section{Perancangan Sistem}

\subsection{Kebutuhan Hardware dan Software}

Agar kinerja sistem aplikasi dapat berjalan secara maksimal diperlukan perlengkapan yang mendukung untuk merancang dan menjalankan sebuah sistem aplikasi. Dalam merancang aplikasi ini, perlengkapan pendukung tersebut adalah perangkat keras dan perangkat lunak.

\subsubsection{Dukungan Hardware}

Hardware atau perangkat keras merupakan peralatan fisik komputer. Beberapa kebutuhan perangkat keras yang digunakan dalam pembuatan aplikasi ini adalah :

a. Laptop dengan spesifikasi :

1. Dell Vostro 1014

2. Processor Intel Core 2 Duo $2 \mathrm{GHz}$

3. VGA Mobile Intel 4 Series Express Chipset Family

4. Hard Disk 250 GB'

5. RAM DDR2 4 GB

b. Smartphone dengan spesifikasi :

1. Sony Ericsson W8

2. RAM $168 \mathrm{MB}$

3. Sitem operasi android v2.3 (Gingerbread)

4. External memory $2 \mathrm{~GB}$ 


\subsubsection{Dukungan Software}

Dalam pembuatan aplikasi ini, digunakan software atau perangkat lunak sebagai berikut :

1. Sistem Operasi Microsoft Windows 7, sebagai sistem operasi yang digunakan komputer.

2. Jdk-7-windows-i586 sebagai java compiler di sistem operasi personal komputer berbasis windows.

3. Intellij IDEA sebagai editor untuk development program berbasis java.

4. Android SDK adalah emulator android sebagai development tool kit android emulator built in intellij IDEA.

\subsection{Perancangan Infrastruktur Jaringan}

Pada dasarnya perancangan infrastruktur jaringan komputer tidak terpaku pada salah satu topologi jaringan saja, namun dapat disesuaikan menurut kondisi lapangan dan kebutuhan sistem. Untuk menghubungkan pelanggan dan restoran terdapat satu buah web server, pelanggan melakukan transaksi pesan melalui aplikasi android. Kemudian manajer mendapatkan notifikasi pesanan, setelah manajer menerima pesan dari pelanggan maka manajer membuat disposisi pesan kepada kitchen. Selanjutnya kitchen membuat disposisi kirim ke petugas delivery, setelah pesanan diantar pada pelanggan maka petugas delivery akan mengirimkan pesan kepada manajer bahwa pesanan telah dikirim.

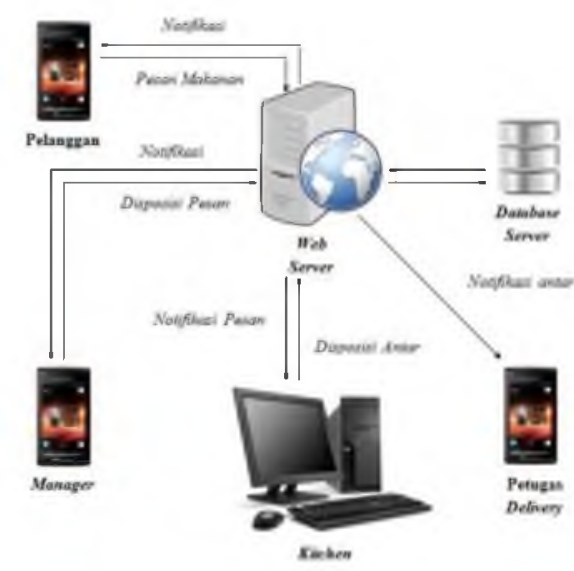

Gambar 3.1 Perancangan Jaringan

\subsection{Perancangan UML (Sistem Layanan Antar Pada Restoran)}

Perancangan aplikasi ini menggunakan UML (Unified Modelling Language) sebagai pemodelan sistem layanan antar pada restoran. Penulis menggunakan tiga jenis pemodelan sistem pada UML, yaitu activity diagram, use case description, dan use case diagram.

\subsubsection{Activity Diagram}

Pada activity diagram sistem layanan antar pada restoran dapat dijelaskan aktifitasaktifitas yang terjadi dalam suatu proses yang dilakukan oleh pelanggan dan admin. Activity diagram sistem layanan antar pada restoran dapat dilihat pada Gambar 3.2. 


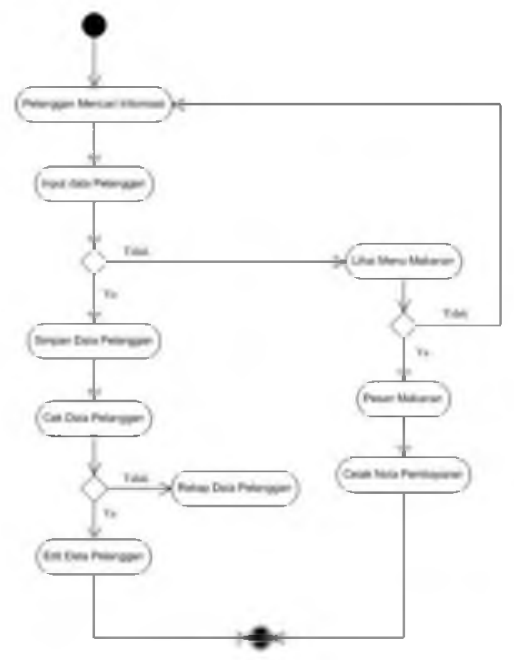

Gambar 3.2 Activity Diagram Sistem Layanan Antar Pada Restoran

\subsubsection{Use Case Description}

Pada use case description sistem layanan antar pada restoran menjelaskan tentang deskripsi atau keterangan dari pelanggan dan admin. Use case description pelanggan dan use case description admin dapat dilihat pada Gambar 3.3 dan Gambar 3.4.

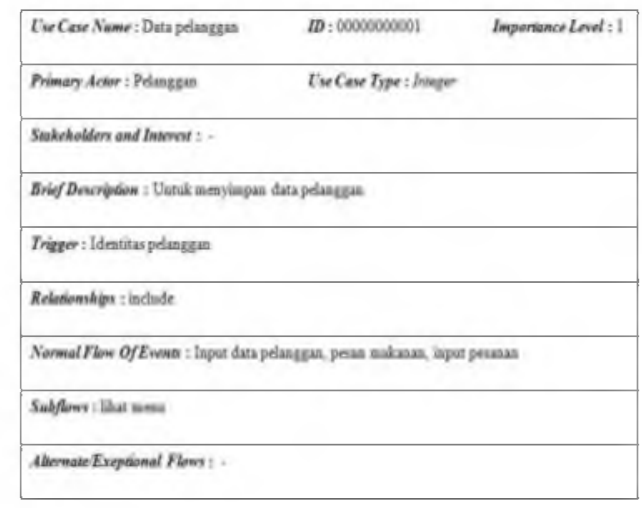

Gambar 3.3 Use Case Description Pelanggan

\begin{tabular}{|c|c|}
\hline TwCaw Same: Datu idmin & Impontencer Loul: : \\
\hline Primany Acar : Ades & tw Caw Type : Loper \\
\hline \multicolumn{2}{|l|}{ Swateholder and huareas: : . } \\
\hline \multicolumn{2}{|c|}{ 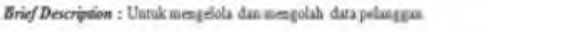 } \\
\hline \multicolumn{2}{|l|}{ Triten: Pelinasu } \\
\hline \multicolumn{2}{|l|}{ Reladumbipe : iadode estends } \\
\hline \multicolumn{2}{|c|}{ 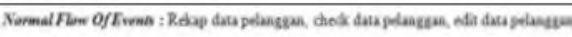 } \\
\hline 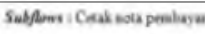 & \\
\hline Ahrmaie Frodienal Flons : = & \\
\hline
\end{tabular}

Gambar 3.4 Use Case Description Admin 


\subsubsection{Use Case Diagram}

Pada use case diagram sistem layanan antar pada restoran dapat dijelaskan kebutuhan dari sisi pengguna (user), aktor dari sistem ini adalah Pelanggan dan Admin. Use case diagram sistem layanan antar pada restoran dapat dilihat pada Gambar 3.5.

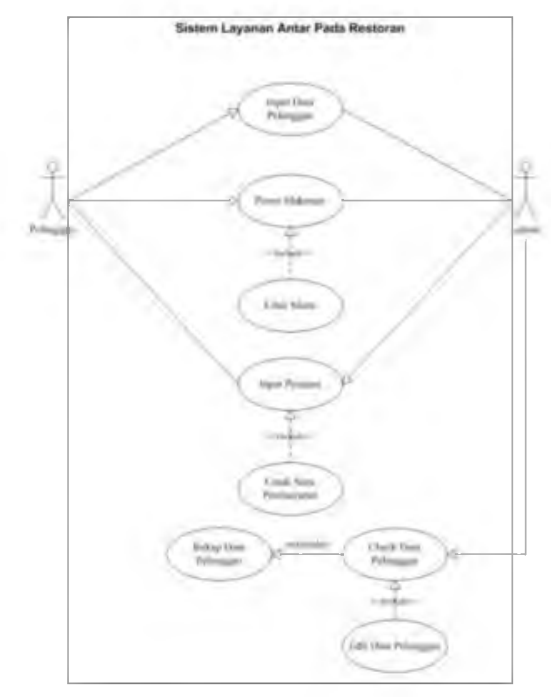

Gambar 3.5 Use Case Diagram Sistem Layanan Antar Pada Restoran

\subsection{Perancangan ORM (Object Relational Mapping)}

Dalam perancangan basis data restoran menggunakan ORM (Object Relational Mapping). ORM melakukan pemetaan terhadap tabel-tabel pada basis data relasional dengan suatu class yang ada pada bahasa pemrograman berorientasi obyek. ORM berfungsi untuk memetakan tabel beserta atribut menjadi kolom. Berikut adalah ORM Sistem Layanan Antar Pada Restoran, dapat dilihat pada Gambar 3.6.

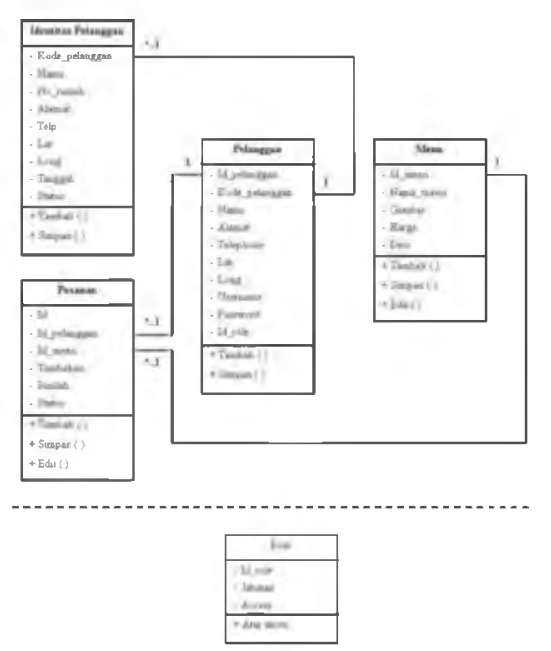

Gambar 3.6 ORM Sistem Layanan Antar Pada Restoran

\subsection{Flowchart Sistem}

Diagram alir atau flowchart adalah gambaran dalam bentuk diagram alir dari algoritmaalgoritma dalam suatu program yang menyatakan arah alur program tersebut. Dalam diagram alir ini akan diketahui jalur dari program secara keseluruhan. Diagram alir 
merupakan suatu model logika data yang dibuat untuk menggambarkan darimana asal data dan tujuan data yang keluar sistem, proses apa yang menghasilkan data tersebut. Pada flowchart sistem terdapat empat flowchart, flowchart untuk aplikasi pelanggan restoran, flowchart untuk aplikasi manager restoran, flowchart untuk aplikasi web kitchen, flowchart untuk aplikasi delivery restoran.

\subsubsection{Flowchart Aplikasi Pelanggan Restoran}

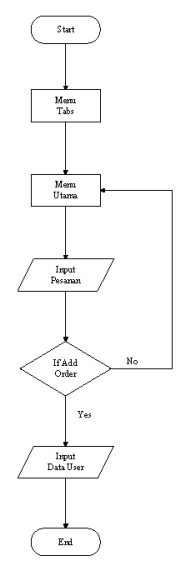

Gambar 3.7 Perancangan Flowchart Aplikasi Pelanggan Restoran

\subsubsection{Flowchart Aplikasi Manager Restoran}

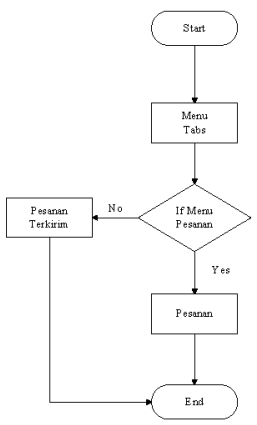

Gambar 3.8 Perancangan Flowchart Aplikasi Manager Restoran

\subsubsection{Flowchart Aplikasi Web Kitchen}

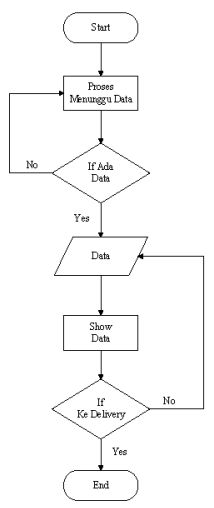

Gambar 3.9 Perancangan Flowchart Aplikasi Web Kitchen 


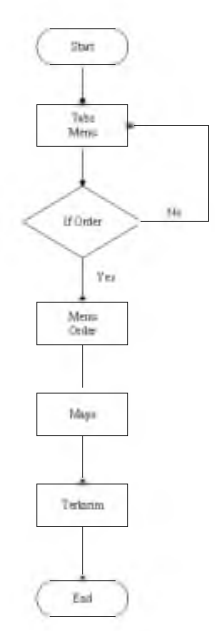

Gambar 3.10 Perancangan Flowchart Aplikasi Delivery

\subsection{Perancangan Antar Muka}

Perancangan antar muka merupakan perancangan tampilan muka sebuah aplikasi dan perancangan antar muka ini akan digunakan untuk melakukan interaksi antara pelanggan dan aplikasi itu sendiri, sehingga perancangan antar muka ini harus diusahakan $u$ ser friendly agar pengguna lebih mudah dalam memakai aplikasi. Dalam aplikasi ini terdapat empat buah interface, yaitu tampilan untuk aplikasi user pelanggan, tampilan untuk aplikasi restoran manager, tampilan untuk aplikasi petugas restoran delivery, dan tanpilan untuk web kitchen.

\subsubsection{Antar Muka User Pelanggan}

Antar Muka utama adalah tampilan jendela utama dari aplikasi user pelanggan yang menghubungkan antara pelanggan dan restoran. Perancangan aplikasi user pelanggan dapat dilihat pada Gambar 3.11 menampilkan menu dari aplikasi, dan menu menu yang terdapat pada antar muka ini adalah sebagai berikut:

1. Daftar menu, terdapat beberapa menu restoran yang dapat dipilih oleh pelanggan.

2. Pada antar muka pesanan anda, terdapat tampilan menu yang dipilih oleh pelanggan.

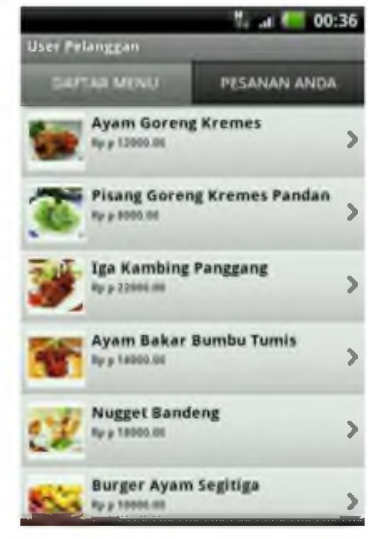

Gambar 3.11 Antar Muka User Pelanggan 


\subsubsection{Antar muka Manager}

Antar muka utama pada manager terdapat beberapa menu untuk melihat pesanan dari pelanggan. Terdapat menu pesanan anda dan menu sudah diantar. Seperti pada Gambar 3.12.

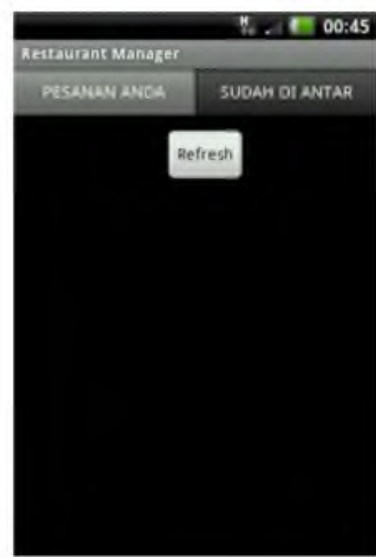

Gambar 3.12 Antar Muka Manager

\subsubsection{Form Web Kitchen (Juru Masak)}

Antar Muka utama web kitchen hanya terdapat satu menu, yaitu menu user pesan. Berfungsi untuk menampilkan daftar menu makanan yang dipesan oleh pelanggan. Dapat dilihat pada Gambar 3.13.

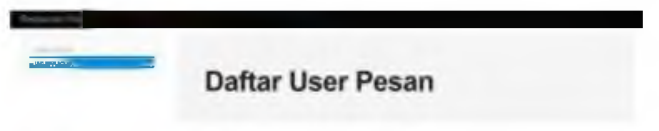

Gambar 3.13 Antar Muka Web Kitchen

\subsubsection{Antar Muka Delivery}

Pada antar muka delivery akan tampil menu pesanan dari pelanggan yang siap diantar oleh petugas delivery kepada pelanggan. Setelah pesanan sampai kepada pelanggan, petugas delivery akan melaporkan pesan kepada manager. Dapat dilihat pada Gambar 3.14. 


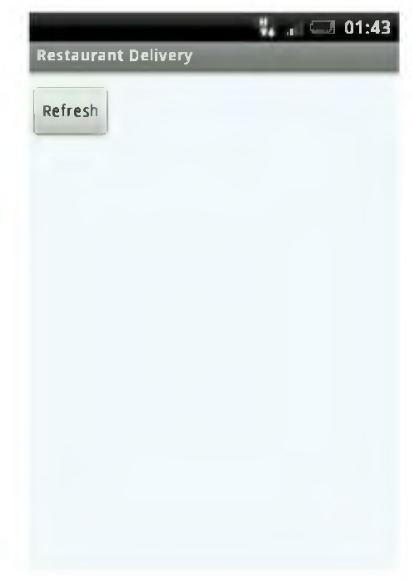

Gambar 3.14 Antar Muka Delivery

\section{Aplikasi Sistem Layanan Antar Pada Restoran}

\subsubsection{Aplikasi Pelanggan}

Aplikasi pelanggan adalah aplikasi yang digunakan sebagai penyedia layanan memesan order makanan oleh pelanggan. Untuk menjalankan aplikasi ini, smartphone android pelanggan harus terhubung ke jaringan internet. Setelah itu mulai mengoperasikan aplikasi pelanggan untuk memesan order makanan.

\subsubsection{Aplikasi Restoran Manager}

Aplikasi restoran manager adalah aplikasi yang digunakan manager untuk menerima order pesanan makanan dari pelanggan. Untuk menjalankan aplikasi ini, smartphone android manager harus terhubung dengan jaringan internet. Kemudian mulai mengoperasikan aplikasi manager untuk melihat order pesanan makanan dari pelanggan.

\subsubsection{Aplikasi Web Kitchen}

Halaman web ini berfungsi untuk menampilkan semua order pesanan makanan dari pelanggan, yang dikirim oleh manager melalui aplikasi restoran manager.

\subsubsection{Aplikasi Restoran Delivery}

Aplikasi restoran delivery adalah aplikasi yang digunakan petugas delivery untuk megirim order pesanan makanan dan mencari lokasi tempat/ rumah user melalui maps yang ada dalam aplikasi tersebut. Untuk menjalankan aplikasi ini, smartphone android yang dibawa oleh petugas delivery harus terhubung dengan jaringan internet. Setelah itu mulai jalankan aplikasi restoran delivery untuk melihat order pesanan makanan siap antar dari kitchen dan mengirim order pesanan tersebut ke pelanggan.

\subsection{Uji Aplikasi}

\subsubsection{Uji Aplikasi Pelanggan}

Untuk dapat menjalankan aplikasi pelanggan, pelanggan harus mempunyai aplikasi pelanggan yang disediakan oleh restoran untuk diinstal pada smartphone android pelanggan. Adapun cara untuk mendapatkan aplikasi tersebut, pelanggan terlebih dahulu mendaftar dan mengisi formulir identitas biodata diri guna mendapatkan aplikasi pelanggan. Setelah smartphone android pelanggan terinstal aplikasi pelanggan, kemudian sambungkan smartphone android pelanggan dengan 
koneksi internet. Berikut gambaran daftar menu makanan, dapat dilihat pada Gambar 4.1.

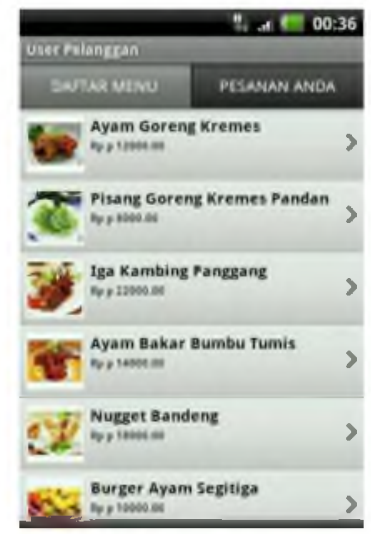

Gambar 4.1 Daftar Menu Makanan

Setelah pelanggan dapat menggunakan aplikasi pelanggan dan melihat daftar menu restoran. Pelanggan dapat melakukan transaksi pesan order makanan dengan cara memilih menu makanan yang ingin dipesan. Kemudian pelanggan mengisi jumlah dan keterangan pesanan yang ingin dipesan sebelum mengklik tombol pesan. Gambaran memilih menu makanan dan isi data pesanan oleh pelanggan, dapat dilihat pada Gambar 4.2.

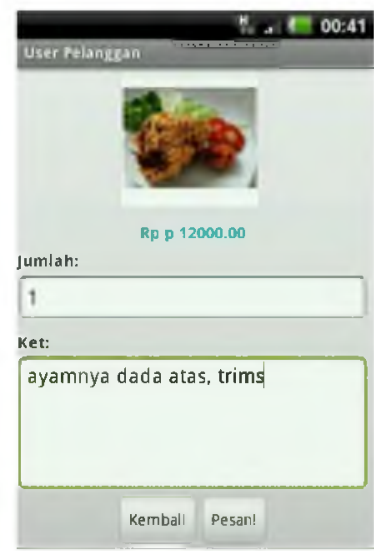

Gambar 4.2 Memilih Menu Makanan dan Isi Data Pesanan Pelanggan

Setelah pelanggan memesan order makanan, pelanggan harus mengisi identitas pelanggan untuk menyelesaikan transaksi pesan order makanan, jika pelanggan tidak mengisi identitas pelanggan atau kurang lengkap dalam mengisi identitas pelanggan maka pelanggan tidak dapat melakukan transaksi pesan order makanan. Gambaran isi data identitas pelanggan, dapat dilihat pada Gambar 4.3. 


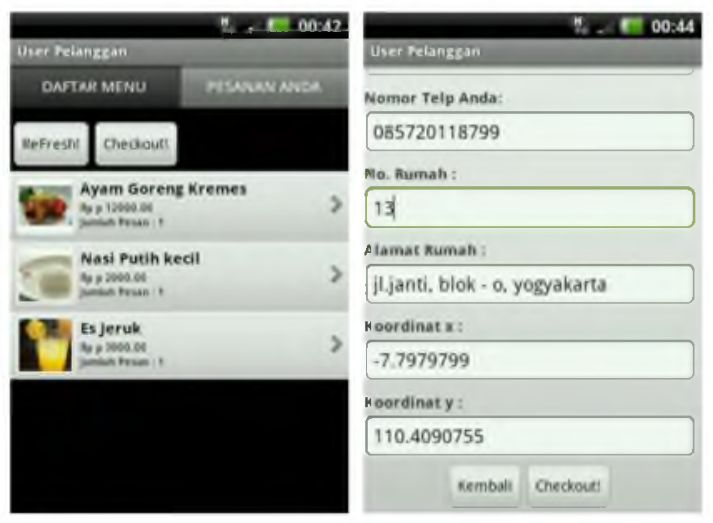

Gambar 4.3 Isi Data Identitas Pelanggan (Checkout)

\subsubsection{Pengujian Aplikasi Restoran Manager}

Untuk dapat menjalankan aplikasi restoran manager yang digunakan oleh manager, smartphone android pengguna harus terinstal aplikasi restoran manager dan tersambung dengan koneksi internet. Kemudian untuk memulai kinerja aplikasi restoran manager, pengguna menunggu apakah ada order pesan makanan dari pelanggan yang masuk di aplikasi restoran manager. Gambaran order pesan makanan pelanggan pada aplikasi pengguna, dapat dilihat pada Gambar 4.4.

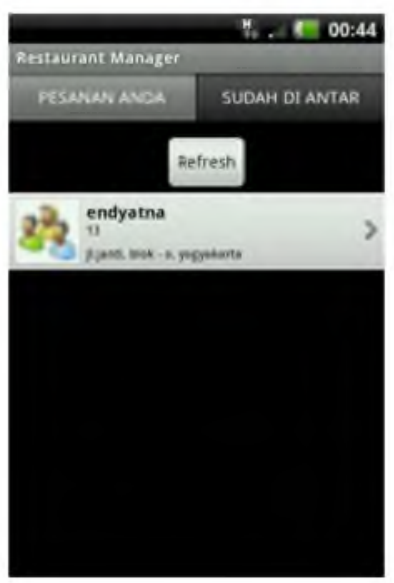

Gambar 4.4 Order Pesan Makanan Pada Aplikasi Restoran Manager

Selanjutnya jika ada order pesan makanan dari pelanggan, maka pengguna harus mengolah data pesanan dengan cara menekan atau menyentuh nama pelanggan yang memesan order makanan di aplikasi restoran manager untuk kemudian mengirim disposisi pesanan ke kitchen. Gambaran disposisi pesanan ke kitchen, dapat dilihat pada Gambar 4.5. 


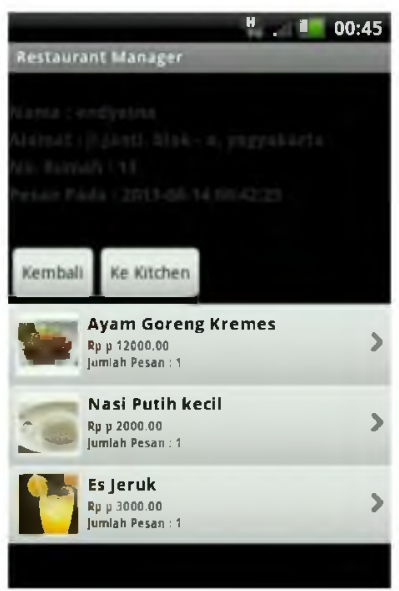

Gambar 4.5 Disposisi Pesanan Ke Kitchen

\subsubsection{Pengujian Aplikasi Web Kitchen}

Aplikasi ini dioperasikan di komputer kitchen yang tersambung dengan koneksi internet. Pada aplikasi web kitchen ini berfungsi untuk menampilkan informasi disposisi pesan yang dikirim oleh manager. Gambaran informasi disposisi pesan pada web kitchen, dapat dilihat pada Gambar 4.6.

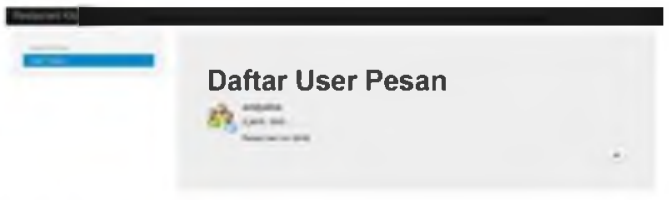

Gambar 4.6 Informasi Disposisi Pesan Pada Web Kitchen

Setelah informasi masuk ke web kitchen, untuk melihat detail pesanan yang dikirim oleh manager, kitchen dapat mengklik tombol yang ada di web kitchen dan mulai memasak. Setelah selesai memasak kemudian kitchen mengirim disposisi antar makanan ke petugas delivery. Gambaran detail makanan dan disposisi antar ke petugas delivery, dapat dilihat pada Gambar 4.7.

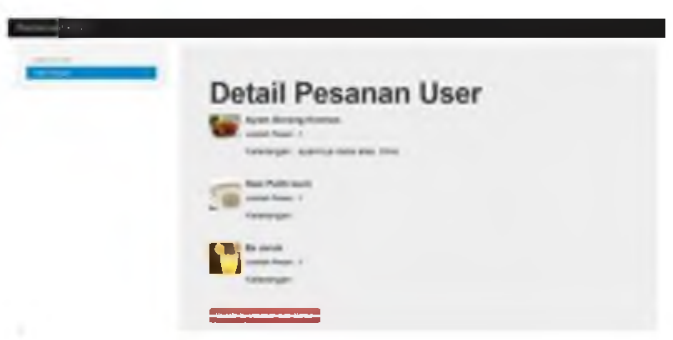

Gambar 4.7 Detail Pesanan dan Disposisi Antar Ke Petugas Delivery

\subsubsection{Pengujian Aplikasi Restoran Delivery}

Untuk dapat menjalankan aplikasi restoran delivery, smartphone android yang digunakan oleh petugas delivery harus terinstal aplikasi restoran delivery dan 
tersambung dengan koneksi internet. Aplikasi ini berfungsi untuk menyimpan data disposisi pesan antar yang dikirim oleh kitchen. Gambaran data disposisi pesan antar, dapat dilihat pada Gambar 4.8.

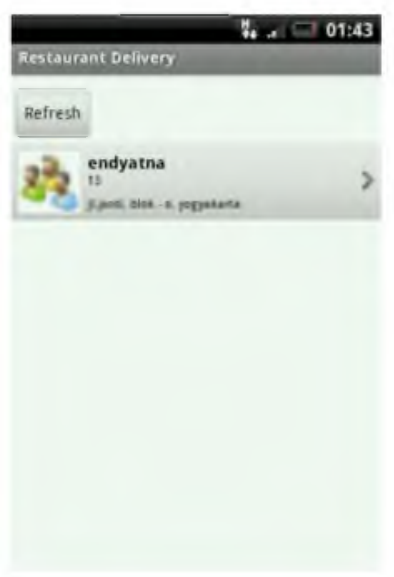

Gambar 4.8 Data Disposisi Pesan Antar

Selain menyimpan data disposisi pesan antar dari kitchen, aplikasi restoran delivery juga berfungsi sebagai alat pandu untuk mengetahui lokasi pelanggan melalui maps yang terdapat pada aplikasi restoran delivery. Untuk melihat lokasi pelanggan petugas delivery dapat menekan atau menyentuh data pesanan pelanggan di aplikasi restoran delivery. Gambaran maps lokasi pelanggan, dapat dilihat pada Gambar 4.9.

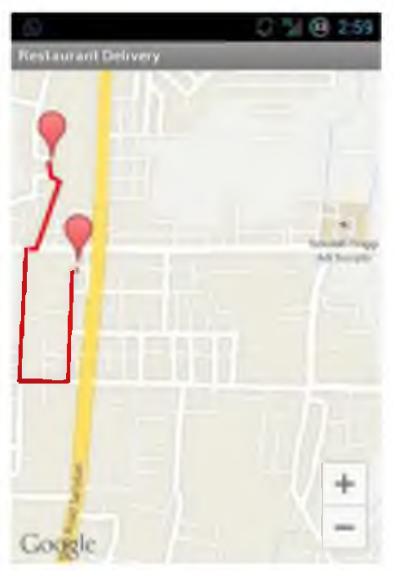

Gambar 4.9 Maps Lokasi Pelanggan

\subsection{Hasil Uji}

\subsubsection{Hasil Uji Smartphone Android}

Pengujian pada beberapa tipe smartphone android yang memiliki sistem operasi yang berbeda mempunyai tujuan untuk mengetahui apakah smartphone android yang diujicoba mendukung apabila diinstal aplikasi pelanggan, aplikasi manager, dan aplikasi delivery. Tipe smarthphone yang diuji antara lain, Sony Ericsson (W8), Sony Xperia Tipo (ST21i), Samsung Galaxy Ace (S5830), dan Sony Ericsson Xperia (X8). Uji smartphone android dapat dilihat pada Tabel 4.1. 
Tabel 4.1 Tabel Ujicoba Smartphone Android

\begin{tabular}{|c|c|c|c|c|c|}
\hline No & $\begin{array}{c}\text { Tipe } \\
\text { Sharpiphone } \\
\text { Androld }\end{array}$ & $\begin{array}{c}\text { Wersi Sistem } \\
\text { Operasi }\end{array}$ & $\begin{array}{l}\text { Djigunakan } \\
\text { Jnntuk } \\
\text { Aplikasi } \\
\text { Pelanggan }\end{array}$ & $\begin{array}{l}\text { Digmakian } \\
\text { Unnuk } \\
\text { Aplikas } \\
\text { Mronager }\end{array}$ & $\begin{array}{c}\text { Ijigunakan } \\
\text { Untuk } \\
\text { Aplii:asi } \\
\text { Delnery }\end{array}$ \\
\hline 1 & $\begin{array}{c}\text { Sony } \\
\text { Iricssan } \\
\text { (Wg) }\end{array}$ & $\begin{array}{c}\mathrm{v} 3 \\
\text { (Gimgerbradad) }\end{array}$ & Mendukamg & Mendulaung & $\begin{array}{c}\text { Tidak: } \\
\text { Mendukmg }\end{array}$ \\
\hline 2 & 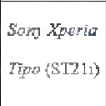 & 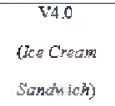 & Mendukmg & Mendukung & Mendukmg \\
\hline 3 & $\begin{array}{l}\text { Srams whg } \\
\text { Gullagy Ace } \\
\text { (S5830) }\end{array}$ & $\begin{array}{c}\text { \%.1 } \\
\text { (Eshy Bewn) }\end{array}$ & Mendukmg & Mendukung & Mendukumg \\
\hline 4 & $\begin{array}{c}\text { Song } \\
\text { Iricsion } \\
x_{\text {peria }}(\mathrm{X})\end{array}$ & V. 1 (Eklair) & $\begin{array}{c}\text { Tidak } \\
\text { Mendukmg }\end{array}$ & $\begin{array}{c}\text { Tidak } \\
\text { Mendukung }\end{array}$ & $\begin{array}{c}\text { Tidak } \\
\text { Mendukumg }\end{array}$ \\
\hline
\end{tabular}

Dari hasil ujicoba pada Tabel 4.1 dapat diambil kesimpulan bahwa smartphone android yang mendukung untuk diinstal aplikasi pelanggan, aplikasi manager, dan aplikasi delivery adalah smartphone android versi 4.0 (Ice Cream Sandwitch) keatas. Smartphone android versi 2.3 (Gingerbread) mendukung apabila diinstal aplikasi pelanggan dan aplikasi manager, untuk aplikasi delivery tidak mendukung. Smartphone android versi 2.1 (Eclair) sama sekali tidak mendukung apabila diinstal aplikasi pelanggan, aplikasi manager, dan aplikasi delivery.

\subsubsection{Hasil Uji Responden}

Pengujian ini dimaksudkan untuk mendapatkan data kegunaan aplikasi bagi pelanggan restoran. Data yang dikumpulkan dalam pengujian ini berasal dari 30 responden. Data yang diperoleh dari 30 responden ini kemudian diolah menjadi data grafik pie untuk memudahkan melihat hasil pengujian dari responden yang menggunakan aplikasi manajemen layanan restoran berbasis android berupa grafik pie.

Adapun pertanyaan fungsi analisis sistem yang diajukan ke responden adalah sebagai berikut :

a. Apakah anda merasa nyaman menggunakan aplikasi ini ? (Ya/Tidak)

b. Apakah efektif dan efisien kalau sistem pelayanan restoran seperti ini benar-benar diterapkan? (Ya/Tidak)

c. Apakah penerapan aplikasi ini dapat meningkatkan efisiensi waktu dalam pemesanan makanan? (Ya/Tidak)

d. Tingkat kepuasan anda atas hasil sistem pelayanan restoran melalui aplikasi layanan antar pada restoran berbasis android ini : (Sangat Puas, Cukup Puas, Kurang Puas, Tidak Puas).

Hasil jawaban responden berupa grafik pie adalah sebagai berikut: 


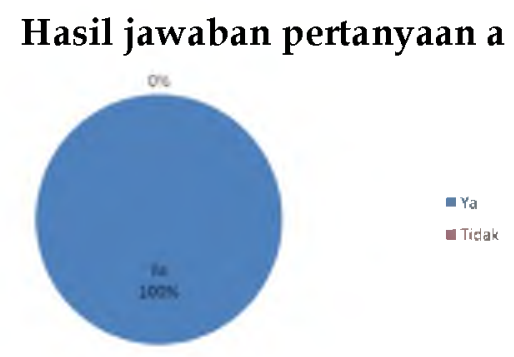

Gambar 4.10 Grafik Pie Hasil Pertanyaan A

Pada Gambar 4.10 merupakan prosentase atas hasil jawaban dari pertanyaan a, yaitu "Apakah anda merasa nyaman menggunakan aplikasi ini ? (Ya/Tidak)". Dari 30 responden semuanya menjawab ya, sehingga prosentasenya $100 \%$, sedangkan yang menjawab tidak prosentasenya $0 \%$.

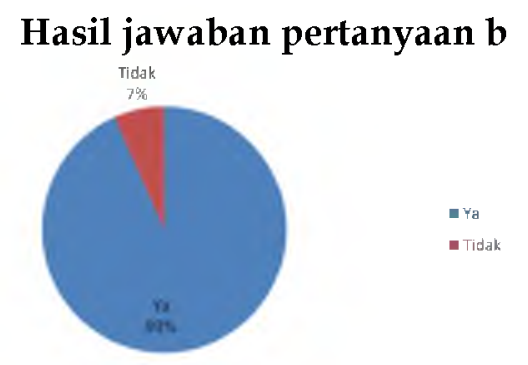

Gambar 4.11 Grafik Pie Hasil Pertanyaan B

Pada Gambar 4.11 merupakan prosentase atas hasil jawaban dari pertanyaan b, yaitu "A pakah efektif dan efisien kalau sistem pelayanan restoran seperti ini benar-benar diterapkan ? (Ya/Tidak)". Dari 30 responden yang menjawab ya sebanyak 28 responden dengan prosentase 93\%, sedangkan yang menjawab tidak sebanyak 2 responden dengan prosentase $7 \%$.

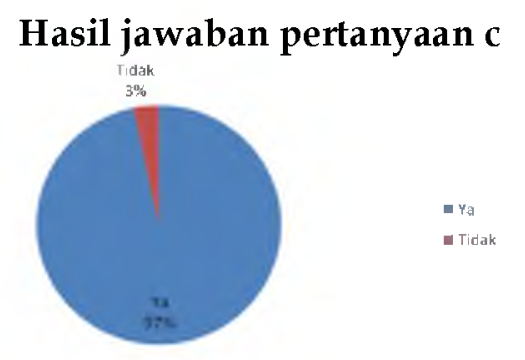

Gambar 4.12 Grafik Pie Hasil Pertanyaan C

Pada Gambar 4.12 merupakan prosentase atas hasil jawaban dari pertanyaan c, yaitu "Apakah penerapan aplikasi ini dapat meningkatkan efisiensi waktu dalam pemesanan makanan ? (Ya/Tidak)". Dari 30 responden yang menjawab ya sebanyak 29 responden dengan prosentase 97\%, sedangkan yang menjawab tidak sebanyak 1 responden dengan prosentase $3 \%$. 


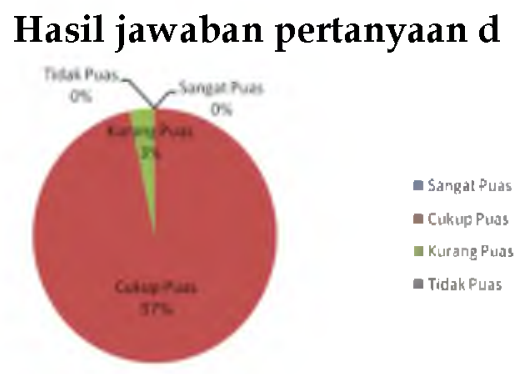

Gambar 4.13 Grafik Pie Hasil Pertanyaan D

Pada Gambar 4.13 merupakan prosentase atas hasil jawaban dari pertanyaan d, yaitu "Tingkat kepuasan anda atas hasil sistem pelayanan restoran melalui aplikasi layanan antar pada restoran berbasis android ini : (Sangat Puas, Cukup Puas, Kurang Puas, Tidak Puas)". Dari 30 responden yang menjawab sangat puas sebanyak 0 responden dengan prosentase $0 \%$, yang menjawab cukup puas sebanyak 29 responden dengan prosentase 97\%, kemudian yang menjawab kurang puas sebanyak 1 responden dengan prosentase $3 \%$, sedangkan yang menjawab tidak puas sebanyak 0 responden dengan prosentase $0 \%$.

\section{Kesimpulan}

Dari hasil pada uji coba yang dilakukan dapat ditarik kesimpulan, sistem layanan antar pada restoran berbasis android yang telah diterapkan ini yaitu:

1. Sistem dapat mempermudah melayani pelanggan restoran pengguna smartphone android dalam pemesanan makanan delivery. Memudahkan petugas delivery mencari lokasi alamat pelanggan untuk mengantar makanan yang dipesan oleh pelanggan.

2. Hasil uji kegunaan sistem dari responden menggunakan aplikasi sistem layanan antar pada restoran sebesar $100 \%$, untuk tingkat efektif dan efisien menggunakan sistem layanan antar pada restoran sebesar 93\%, untuk efisiensi waktu menggunakan sistem layanan antar pada restoran sebesar 97\%, untuk tingkat kepuasan responden menggunakan sistem layanan antar pada restoran sebesar $97 \%$.

\section{Daftar Pustaka}

[1] Alan Dennis Dkk, 2005, System Analysis And Design With UML Version 2.0, Virginia : Phoenix Color Corp.

[2] Alqod Elian Dkk, 2012. Layanan Informasi Kereta Api Menggunakan GPS, Google Maps, dan Android. Jurnal Teknik Informatika Institut Teknologi Sepuluh November Volume 1, Nomor 1, 2012 : Surabaya.

[3] Antok Supriyanto, Bre Sukma Kirana, 2008, Sistem Informasi Manajemen Pemesanan Makanan Cepat Saji Melalui Internet Dengan Multi Outlet. Proceeding Seminar Nasional Informatika STIKOM ISSN 1979-2328 : Surabaya.

[4] Awang Hendrianto Pratomo, 2008, Pengembangan Aplikasi Sistem Pendukung Keputusan Pemilihan Makanan Sehat Berbasis SMS. Proceeding Seminar Nasional Informatika UPN "Veteran" ISSN 1979-2328 : Yogyakarta. 
[5] Bangun Wijayanto, 2011. Implementasi Object Relational Mapping (ORM) Menggunakan Hibernate. Proceeding Seminar Nasional Aplikasi Teknologi Informasi Universitas Jenderal Soedirman ISSN 1907-5022 : Yogyakarta.

[6] Elihu Setyo Nugroho, 2012. Manajemen Web Untuk Mendukung Aplikasi Informasi Peta Digital Pada Smartphone Berbasis Android. Compiler Journal Adisutjipto Informatics Society Volume 1, Nomor 2, 2012 : Yogyakarta.

[7] Fariz Irawan, 2010.Aplikasi Bergerak Untuk Pemesanan Makanan Di Cupcakes Heaven Via SMS (Short Message Service). Jurnal Fakultas Ilmu Komputer Universitas Mercu Buana Volume 9, Nomor 1, 2010 : Jakarta.

[8] Gandhi Pawitan, 2008, Aplikasi Analisis Pareto Dalam Pengendalian Inventori Bahan Baku Pada Bisnis Restoran. Jurnal Jurusan Administrasi Bisnis UNPAR Volume 4, Nomor 1, 2008 : Bandung.

[9] Ivan Michael Siregar Dkk, 2010, Mengembangkan Aplikasi Enterprise Berbasis Android, Gava Media : Yogyakarta.

[10] Lily Wulandari, I Wayan Simri Wicaksana, 2006. Toward Web Service. Proceeding Seminar Ilmiah Nasional Komputer dan Sitem Intelijen Auditorium Gunadarma ISSN 1411-6286 : Depok.

[11] Mulyadi, ST, 2010, Membuat Aplikasi Untuk Android, Multimedia Center Publishing : Yogyakarta.

[12] Tjandra Susila Dkk, 2006. Perancangan Alat Pemesanan Makanan Di Restoran Secara Wireless. Jurnal TESLA Teknik Elektro Universitas Tarumanagara Volume 8, Nomor 2, 2006 : Jakarta. 